Article

\title{
High Transmission Potential of West Nile Virus Lineage 1 for $C x$. pipiens s.l. of Iran
}

\author{
Hasan Bakhshi ${ }^{1}{ }^{10}$, Laurence Mousson ${ }^{2}$, Marie Vazeille ${ }^{2}$, Sedigheh Zakeri ${ }^{1}$, Abbasali Raz ${ }^{1}$, \\ Xavier de Lamballerie ${ }^{3}$, Navid Dinparast-Djadid ${ }^{1, *}$ and Anna-Bella Failloux ${ }^{2, *}$ (D) \\ 1 Malaria and Vector Research Group, Biotechnology Research Center, Pasteur Institute of Iran, \\ Tehran P.O. Box 1316943551, Iran; hbakhshi89@gmail.com (H.B.); zakeris@yahoo.com (S.Z.); \\ raz.biotech@gmail.com (A.R.) \\ 2 Institut Pasteur, Arboviruses and Insect Vectors, 75724 Paris, France; laurence.mousson@pasteur.fr (L.M.); \\ marie.vazeille@pasteur.fr (M.V.) \\ 3 Unité des Virus Emergents (UVE), Aix Marseille Université, IRD 190, INSERM 1207, IHU Méditerranée \\ Infection, 13005 Marseille, France; xavier.de-lamballerie@univ-amu.fr \\ * Correspondence: navidmvrg@gmail.com (N.D.-D.); anna-bella.failloux@pasteur.fr (A.-B.F.)
}

Received: 22 February 2020; Accepted: 2 April 2020; Published: 3 April 2020

\begin{abstract}
Vector competence is an important parameter in evaluating whether a species plays a role in transmission of an arbovirus. Although the protocols are similar, interpretation of results is unique given the specific interactions that exist between a mosquito population and a viral genotype. Here, we assessed the infection (IR), dissemination (DR), and transmission (TR) rates of $C x$. pipiens s.l., collected from Iran, for West Nile virus (WNV) lineage 1a. We showed that $C x$. pipiens s.l. mosquitoes in Iran were susceptible to $\mathrm{WNV}$ with IR up to $89.7 \%, 93.6 \%$, and $83.9 \%$ at 7,14 , and 21 days post-infection (dpi) respectively. In addition, DR and TR reached respectively $92.3 \%$ and $75.0 \%$ at $21 \mathrm{dpi}$, and the number of viral particles delivered with saliva reached up to $1.33 \times 10^{5}$ particles. Therefore, an unexpected high risk of WNV dissemination in the region where $C x$. pipiens s.l. mosquitoes are well established should be considered carefully and surveillance measures implemented accordingly.
\end{abstract}

Keywords: West Nile virus; vector competence; experimental infections; Iran

\section{Introduction}

Mosquito-borne viruses, such as dengue, chikungunya, Zika, and West Nile virus, are responsible for millions of disease cases and thousands of deaths each year [1]. West Nile virus (WNV; family Flaviviridae, genus Flavivirus) is the most widespread arbovirus in the world and can be fatal for humans [2]. WNV was isolated for the first time in 1937 from Uganda [3] and Cx. pipiens is considered as one of its primary enzootic vectors [4]. This vector is widely distributed in many countries [5]. WNV is now spread in Southern Asia, Northern Australia, Africa, and temperate regions of Europe [6,7]. The increasing traffic of goods and animals between countries offers multiple opportunities for the introduction of arboviruses in Iran, including WNV [8,9]. WNV is the most prevalent Culex-transmitted virus frequently reported in the country $[10,11]$. Approximately, $20 \%$ of WNV-infected people show a symptomatic infection [12]. Clinical symptoms are non-specific to the disease, including anorexia, fever, and headache. This virus is separated into two main lineages: (i) Lineage 1 is widely distributed and highly invasive and includes most strains responsible for outbreaks in the Middle East, India, Europe, and Australia [13]; this lineage is differentiated into three clades 1a, 1b, and 1c, with viruses of clade 1a found worldwide [14] and (ii) Lineage 2 was used to be endemic to some regions of Africa [14]; however, its circulation has been recently reported in Europe, Sub-Saharan Africa, Madagascar, and the Middle East, including Iran [7,15-19]. Lineage 2 has caused many human cases of neuroinvasive 
disease in Greece [20,21] and Italy [22], suggesting that it also can be as pathogenic as lineage 1 . The amino acid identity among members of the two lineages is around $93.2 \%-94 \%$ [23].

WNV infection was first investigated in Iran in 1970 and, subsequently, additional investigations on mosquitoes, including Cx. pipiens s.l. as the main WNV vector [24], humans, horses, and birds, confirmed the presence of the virus in the country [25]. There is much serological and molecular evidence of WNV circulation in vectors, animal reservoirs, and dead end hosts in Iran [9,17,18,26-30]. Nevertheless, only few studies have succeeded in identifying the WNV lineages circulating in the country $[15,17,18]$ : $C x$. pipiens s.l. mosquitoes have been found to be infected with WNV belonging to lineage 2 [18]. In addition, lineage 1 of WNV has been recently detected in blood donors of Pakistan (east of Iran) [31] and in mosquito pools, Aedes albopictus and Cx. pipiens s.l., in Turkey (northwest of Iran) [32]. Other similar investigations have also proved the circulation of WNV lineage 1 in Turkey, bordered with Iran [33-35].

To get a precise view on how a vector-borne disease can become a global disease, information on vector competence of mosquitoes from different regions in the world is essential. Vector competence is an important parameter in evaluating whether a species plays a role in transmission of a pathogen in the field. Although assessments are based on common protocols, the outcome is unique, as different mosquito genotypes and virus genotypes (described under GxG interactions) are used [36].

Detection of an arbovirus in a vector does not indicate alone that the mosquito is a competent vector for the virus. The distribution of WNV in the country is widespread as it can be transmitted by a broad range of vectors and can infect different vertebrate hosts [25]. Despite the important role of vectors in the WNV biological cycle, there is no study on vector competence for WNV of mosquitoes in the region. More knowledge about transmission potential of mosquito vectors will provide important clues on risks of emergence or re-emergence of WNV in the area. Thus, for a better understanding of the mechanisms behind the maintenance and transmission of WNV, the present study was designed to evaluate the vector competence of $C x$. pipiens s.l., the principal vector of WNV [37], and one of the most prevalent species reported [38] for the highly invasive and recently reported WNV lineage 1 in the region [31,32], based on measuring the infection, dissemination, and transmission rates of $C x$. pipiens s.l. for WNV lineage 1a.

\section{Materials and Methods}

\subsection{Ethic Statements}

Laboratory rabbits were housed in the Institut Pasteur animal facilities accredited by the French Ministry of Agriculture to use their blood. Work on animals was performed in compliance with French and European regulations on care and protection of laboratory animals (EC Directive 2010/63, French Law 2013-118, 6 February 2013). All experiments were approved by the Ethics Committee \#89 and registered under the reference APAFIS\#6573-2016061412077987 v2.

\subsection{Culex Pipiens Collection and Rearing}

According to the standard dipping technique (350 mL dipper), Culicinae mosquito larvae were collected from Ghorogh forest $\left(36^{\circ} 50^{\prime} \mathrm{N} 54^{\circ} 26^{\prime} \mathrm{E}\right)$, located in Golestan province, northeast of Iran, in 2015. Larvae of $C x$. pipiens from pipiens (as well as the emerged adults) were identified using morphological characteristics [39] and molecular markers (Genbank accession number for cytochrome oxidase I gene: KY646203) and reared in insectaries under standardized conditions $\left(26 \pm 2{ }^{\circ} \mathrm{C}, 70 \pm 10 \%\right.$ relative humidity, $12 \mathrm{~h}: 12 \mathrm{~h}$ light:dark photoperiod). Larvae were placed in dechlorinated water, supplemented with fish-powdered food. Emerging adults were collected daily and transferred into cages, where they were fed with a $10 \%$ glucose solution. 


\subsection{Vector Competence Assay}

WNV experimental infections were run at the Institut Pasteur in Paris [40]. In brief, 5 to 7-day-old females were transferred to boxes, starved for $48 \mathrm{~h}$ in a biosafety level 3 insectary, and then allowed to feed for $20 \mathrm{~min}$ through a pig intestine membrane covering the base of a capsule of the feeding system Hemotek ${ }^{\circledR}$, containing the blood-virus mixture maintained at $37^{\circ} \mathrm{C}$ [41]. The infectious meal was composed of WNV suspension diluted in phosphate buffered saline (PBS)-washed erythrocytes from rabbit [40] to obtain a titer of $10^{7.3} \mathrm{pfu} / \mathrm{mL}$. The adenosine triphosphate (ATP) was added as a phagostimulant at a final concentration of $5 \times 10^{-3} \mathrm{M}$. The WNV belonged to lineage 1a (Genbank accession number: AY268132), which was isolated from a horse in France (Camargue) in 2000 [42]. Viral stocks were produced on Aedes albopictus cells C6/36 [43] after four passages on Vero cells and stored at $-80^{\circ} \mathrm{C}$ in aliquots until use. After exposure to the infectious blood meal, fully engorged females were transferred in cardboard containers and maintained with $10 \%$ sucrose at $28 \pm 1^{\circ} \mathrm{C}$ for 21 days. To evaluate the vector competence of $C x$. pipiens, the infection rates (IRs) were assessed at 7 (29 samples), 14 (31 samples), and 21 (31 samples) days post-infection (dpi) by the RT-qPCR method. To confirm the infection of mosquitoes to WNV, three engorged mosquitoes were homogenized, and the presence of virus was confirmed by the RT-qPCR method at 0 dpi. The dissemination rate (DR), transmission rate (TR), dissemination efficiency (DE), and transmission efficiency (TE) of the samples at $21 \mathrm{dpi}$ were assessed, as described below.

The total RNA of the 125 (0 dpi: 3; 7 dpi: 29; 14 dpi: 31; 21 dpi for IR assay: 31; 21 dpi for DR assay: 31) infected mosquitoes were extracted using a Macherey-Nagel NucleoSpin ${ }^{\circledR}$ RNA extraction kit (Hoerdt, France). Total WNV RNA was quantified by RT-qPCR using the Bio-Rad CFX96 ${ }^{\mathrm{TM}}$ Real-Time PCR Detection System and Power SYBR ${ }^{\circledR}$ Green RNA-to-C $\mathrm{T}_{\mathrm{T}}$ 1-Step kit. For each reaction, we used $10.55 \mu \mathrm{L}$ of distilled water, $12.5 \mu \mathrm{L}$ of buffer $2 \mathrm{X}, 0.375 \mu \mathrm{L}(10 \mathrm{mM})$ of each designed forward and reverse primers (WN175up: 5'-GTGTTGGCTCTCTTGGCGTT-3' and WN259low: 5'-AGGTGTTTCATCGCTGTTTG-3'), $0.2 \mu \mathrm{L}$ of mix-enzyme $125 \mathrm{X}$, and $1 \mu \mathrm{L}$ of RNA. The reverse transcription was performed at $48{ }^{\circ} \mathrm{C}$ for $30 \mathrm{~min}$. The qPCR conditions were $95^{\circ} \mathrm{C}$ for $10 \mathrm{~min}$, followed by 40 amplification cycles of $95^{\circ} \mathrm{C}$ for $15 \mathrm{~s}$ and $60^{\circ} \mathrm{C}$ for $1 \mathrm{~min}$. Additionally, melt curve assay $\left(65^{\circ} \mathrm{C}\right.$ to $92{ }^{\circ} \mathrm{C}$ : Increment of $\left.0.5^{\circ} \mathrm{C} 0: 05\right)$ was carried out. For each run, the number of WNV RNA copies was calculated by absolute quantitation using a standard curve, which was generated using duplicates from $10^{2}$ to $10^{8}$ copies of RNA synthetic transcripts per reaction. Quantification of viral RNA was achieved by comparing the threshold cycle $(\mathrm{Ct})$ values of samples to those of standards, according to the $\Delta \mathrm{C}_{\mathrm{t}}$ analysis.

To estimate viral transmission, saliva was collected from individual mosquitoes as described before [44]. For collection, the wings and legs were removed from each mosquito and the proboscis was inserted into a $20 \mu \mathrm{L}$ tip, containing $5 \mu \mathrm{L}$ of Fetal Bovine Serum (FBS). After 45 min of salivation, FBS containing saliva was expelled into $45 \mu \mathrm{L}$ of Leibovitz L15 medium for titration. Infectious viral particles were detected in saliva by a plaque forming unit (pfu) assay on Vero E6 cell monolayers, as previously described [45]. Four parameters were calculated: (1) IR, corresponding to the proportion of $C x$. pipiens species with an infected midgut among tested mosquitoes; (2) DR, indicating the proportion of $C x$. pipiens species with an infected head among mosquitoes whose midguts were infected; (3) TR, defined as the proportion of mosquitoes with infectious saliva among $C x$. pipiens species with an infected head, and (4) TE, showing the proportion of $C x$. pipiens species with infectious saliva among all individuals tested [46].

\subsection{Statistical Analysis}

Rates, means, standard error (SE), and standard deviation (SD) were calculated, and statistical analyses were performed using the Stata software. $p$-values of $<0.05$ were considered statistically significant. 


\section{Results}

\subsection{Artificial Feeding}

In total, 367 female adults were exposed to an infectious blood meal. Out of 367, 275 (74.9\%) females successfully fed on the WNV-infected blood. Out of 275 blood fed females, 125 mosquitoes survived until the day of examination.

\subsection{Viral Infection Over Time}

Viral IRs at 7, 14, and 21 dpi were 26/29 (mean (\%) \pm SE: 89.7\% \pm 5.7), 29/31 (93.5\% \pm 4.5 ), and 26/31 (83.9\% \pm 6.7$)$, respectively (Figure 1A); despite variations, IRs were not significantly different $\left(\chi^{2}\right.$ test: $\left.p=0.472\right)$. In addition, the viral load in bodies were $5.8 \log _{10} \pm 0.9(26)(\operatorname{mean} \pm \operatorname{SD}(n))$ at $7 \mathrm{dpi}, 6.2 \log _{10} \pm 1.7$ (29) at $14 \mathrm{dpi}$ and $6.8 \log _{10} \pm 1.8$ (26), showing a significant increase in viral loads over time (Kruskal-Wallis test: $p=0.0001$ ) (Figure 1B).

(A)

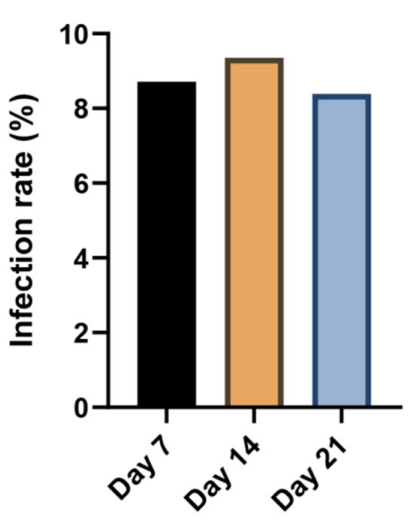

(B)

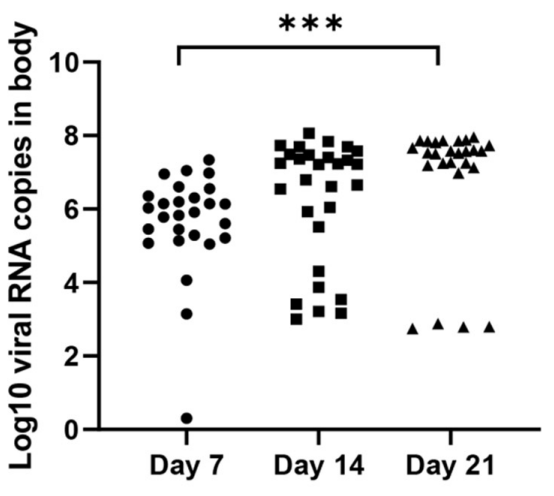

Figure 1. Infection rate (A) and viral RNA copies measured in bodies (B) at 7, 14, and 21 days after exposure of Culex pipiens s.l. to West Nile virus at a titer of $10^{7.3} \mathrm{pfu} / \mathrm{mL}$. Viral RNA particles were detected within bodies by RT-qPCR. ${ }^{* *} p \leq 0.001$.

\subsection{Dissemination and Transmission at 21 Days Post-Infection}

Among 31 mosquitoes examined at $21 \mathrm{dpi}, 26(83.9 \% \pm 6.7)$ had an infected body and, among these, $24(92.3 \% \pm 5.3)$ had ensured viral dissemination with virus detected in the head. Among these 24 mosquitoes, $18(75.0 \% \pm 9.0)$ were able to transmit the virus with viral particles detected in mosquito saliva (Figure 2A). When examining viral RNAs, the number in bodies $\left(6.8 \log _{10} \pm 1.8\right)$ and heads $\left(7.3 \log _{10} \pm 1.0\right)$ were not significantly different (Mann-Whitney test: $p=0.56$ ) (Figure 2B). When considering transmitted viruses, mosquito saliva contained a mean of $1.7 \mathrm{Log}_{10}$ viral particles $( \pm 1.1)$ in 18 mosquitoes, a number significantly lower than in the body and head (Kruskal-Wallis test: $p=0.0001$ ) (Figure 2C). To measure the ability of mosquitoes to allow the virus to be transmitted with the saliva, the transmission efficiency $(\mathrm{TE} ; 58.0 \pm 9.0)$ was calculated, corresponding to the product of DE $(77.4 \%$ $\pm 7.6)$ and $\operatorname{TR}(75 \% \pm 9.0)$. 
(A)

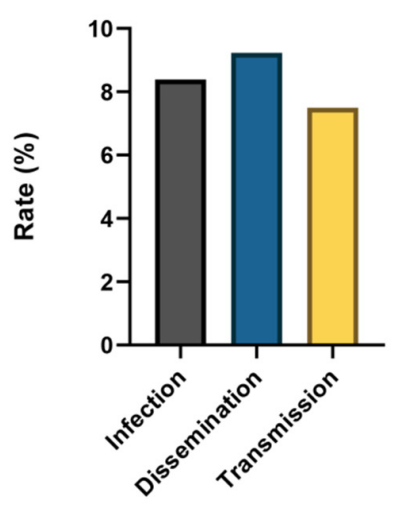

(B)

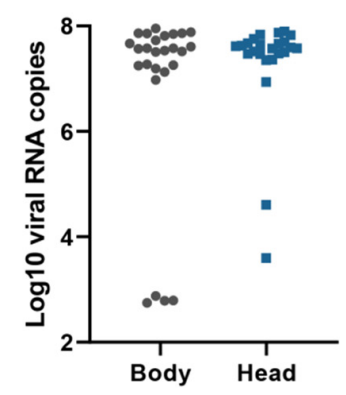

(C)

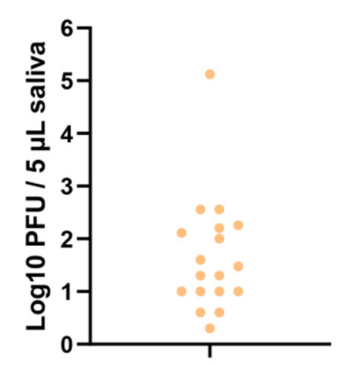

Figure 2. Infection, dissemination, and transmission rates (A); viral RNA copies in the body and head (B); and viral particles in saliva (C), 21 days after challenging Culex pipiens s.l. with West Nile virus at a titer of $10^{7.3} \mathrm{pfu} / \mathrm{mL}$.

\section{Discussion}

To date, many experimental studies have focused on assessing the vector competence to evaluate the potential for WNV emergence and spread among mosquito populations [37,41,47-55], as well as other suspected hematophagous arthropods, including ticks [56]. Given its high local abundance and its feeding behavior towards birds and mammals, $C x$. pipiens s.l. is a key vector of WNV in Iran [57] and in the world [58].

Recent investigations have detected field-collected $C x$. pipiens mosquitoes, infected with WNV in Iran $[9,18]$. However, despite many other signs of WNV circulation based on serological and molecular detections in humans, horses, birds, and mosquitoes, the vector competence of this species remains unknown in the country. A large range of Aedes and Culiseta mosquito species (Ae. caspius mosquitoes) have been found to be infected with WNV in the northwest of Iran [15]), which are also efficient for transmitting WNV at even lower rates [51]. Interestingly, the experimental transmission of WNV by ticks [59] and by mites [60] has been attempted without any clear evidence. $C x$. pipiens s.l. is described under two biological forms, pipiens and molestus, which are morphologically indistinguishable [61]. The Ghorogh Forest mosquito strain used in this study belongs to the pipiens form, which has been shown to be a primary vector of WNV in the Mediterranean basin [47].

After feeding on a viremic host, WNV must penetrate into the midgut epithelial cells and replicate. Subsequently, WNV must disseminate within tissues of the mosquito internal organs. To be injected into a new vertebrate host, WNV should infect the salivary glands [62]. The efficiency of barriers in mosquito vectors determines the level of mosquito vector competence [47]. Vector competence is mainly influenced by environmental temperature, as well as viral dose [63]. Arboviruses transmitted by mosquito vectors have seen their range of geographic distribution changing as a consequence of environmental modifications, creating suitable conditions to the establishment of their vectors combined with human activities, favoring passive transportation of mosquitoes. WNV presents one of the highest potentials to re-emerge as numerous mosquitoes, and birds are efficient transmitters with recurrent spillovers to equines and humans. Clear associations have been found between warm conditions and WNV outbreaks in various countries of the world [64]. Laboratory experiments have revealed that up to $100 \%$ of $C x$. tarsalis mosquitoes become infected after feeding on blood containing a WNV concentration of $10^{7.1} \mathrm{pfu} / \mathrm{mL}$, while in a blood containing $10^{4.9} \mathrm{pfu} / \mathrm{mL}$, only up to $36 \%$ become infected [51]. It has been shown that the infectious doses required for infection of $C x$. pipiens must be greater than $10^{5.0} \mathrm{pfu} / \mathrm{mL}$ [65]. In this investigation, we used a viral titer of $10^{7.3} \mathrm{pfu} / \mathrm{mL}$ and an incubation temperature of $28^{\circ} \mathrm{C}$.

The results of the present investigation revealed that IRs were not significantly different and varied from $83.9 \%$ to $93.5 \%$. (Figure $1 \mathrm{~A}$ ); however, the viral load in bodies varied from $5.8 \log _{10}$ to $6.8 \log _{10}$, 
showing a significant increase in viral loads over time (Figure 1B). We also observed a viral DR and TR of $92.3 \%$ with virus detected in the head, containing a mean of $7.3 \log _{10} \pm 1.0$ viral particles, and $75 \%$ with viral particles detected in mosquito saliva, containing a mean of $1.7 \log _{10}$ at $21 \mathrm{dpi}$, respectively (Figure 2A-C). A TE of 58\% was also calculated. The number of viral particles delivered with saliva was up to $1.33 \times 10^{5}$ particles (Figure $2 \mathrm{~A}$ ). Based on the evaluation of IR, DR, and TRs, Cx. pipiens s.l. populations collected from the north of Iran were highly susceptible to WNV lineage 1a, with infection rates higher than $89.7 \%$ and viral loads in bodies higher than $5.8 \log _{10}$ from $7 \mathrm{dpi}$. At $21 \mathrm{dpi}$, viral infection, dissemination, and transmission were not hampered, suggesting a minor role of the two anatomical barriers, midgut, and salivary glands in the migratory route of the virus until mosquito saliva. Mosquitoes can then excrete an average of $1.7 \log _{10}$ viral particles (Supplementary Table S1).

For the WNV, mosquito genotype has a significant role in specific interactions between virus genotypes and mosquito vectors and influences the outcome of transmission of WNV [66]. Our results are consistent with former investigations in Lebanon [41] and the Maghreb region [47], carried out with the same WNV strain used in this study, corroborating the high IRs of Cx. pipiens colonies for WNV lineage 1. In Lebanon, Zakhia et al., (2018) showed IRs ranging from 94.7 to 100\% from 3 to 19 dpi, DEs (compared to DR, DE indicates the proportion of mosquitoes with an infected head among all mosquitoes tested) increasing from 31.6\% (3 dpi) to $94.7 \%$ (19 dpi), TEs gradually increasing from $10.5 \%$ at $3 \mathrm{dpi}$ to $68.4 \%$ at $19 \mathrm{dpi}$, and the viral load reaching $1028( \pm 405) \mathrm{pfu} / \mathrm{saliva}$ at $19 \mathrm{dpi}$ [41]. Amraoui et al., (2012) also showed that Cx. pipiens mosquitoes from the Maghreb region were efficient experimental vectors to transmit WNV: at $21 \mathrm{dpi}$, TRs reached $80 \%$, with a mean number of infectious particles in saliva of $1.7 \pm 0.9 \log _{10} \mathrm{pfu}$, DRs ranged from $59.1 \%$ to $100 \%$, and TRs varied from $25 \%$ to $83.3 \%$ [47]. On the other hand, it has been shown that $C x$. pipiens mosquitoes were moderately efficient vectors of this virus in France with a TR of $15.8 \%$ at 14 dpi [48], as did Cx. tarsalis [54], Cx. modestus [49], Cx. Quinquefasciatus, and Cx. nigripalpus [52].

Vector competence assays should be combined with an active monitoring of WNV lineage 1 circulation in Iran [31,32]. We used a lineage 1 strain to assess vector competence of Cx. pipiens s.l. mosquitoes; we suggest that vector competence would be quite similar if testing with other strains of lineage 1. Further studies should be done using strains of lineage $2[15,17,18]$, which can be as pathogenic as lineage 1.

In conclusion, our results showed an unexpected high transmission potential of WNV lineage 1 by $C x$. pipiens s.l. of Iran, meaning that outbreaks are to be feared as active circulation of WNV operates in the region. Thus, local health authorities are suggested to establish an active surveillance with an early detection of WNV infection in field-collected mosquito vectors.

Supplementary Materials: The following are available online at http://www.mdpi.com/1999-4915/12/4/397/s1, Table S1: Details of the mosquitoes used in the present investigation, their SQ mean (RT-qPCR) and saliva titer (pfu/saliva).

Author Contributions: Conceptualization, A.-B.F. and H.B.; sample collection, H.B.; experiments, H.B., L.M., and M.V.; formal analysis, A.-B.F.; investigation, H.B., L.M., and M.V.; writing-original draft preparation, H.B., A.-B.F., N.D.-D., S.Z., A.R., and X.d.L. All authors have read and agreed to the published version of the manuscript.

Funding: The present article is a part of a project that has been supported through a grant from Institut Pasteur International Network (IPIN, MATI) to ABF and NDD. HB as a Ph.D. student of medical biotechnology also received scholarships from IPP, Campus France, and education office of IPI.

Acknowledgments: The present article is a part of a project that has been supported through a grant from Institut Pasteur International Network (IPIN, MATI) to ABF and NDD. HB as a Ph.D. student of medical biotechnology also received a scholarship from IPP, Campus France, and education office of IPI.

Conflicts of Interest: The authors declare no conflict of interest. 


\section{References}

1. Caraballo, H.; King, K. Emergency department management of mosquito-borne illness: Malaria, dengue, and West Nile virus. Emerg. Med. Pract. 2014, 16, 1-23. [PubMed]

2. Kramer, L.D.; Styer, L.M.; Ebel, G.D. A global perspective on the epidemiology of West Nile virus. Annu. Rev. Entomol. 2008, 53, 61-81. [CrossRef] [PubMed]

3. Smithburn, K.; Hughes, T.; Burke, A.; Paul, J. A neurotropic virus isolated from the blood of a native of Uganda1. Am. J. Trop. Med. Hyg. 1940, 1, 471-492. [CrossRef]

4. Andreadis, T.G. The contribution of Culex pipiens complex mosquitoes to transmission and persistence of West Nile virus in North America. J. Am. Mosq. Control. Assoc. 2012, 28, 137-152. [CrossRef]

5. Conley, A.K.; Fuller, D.O.; Haddad, N.; Hassan, A.N.; Gad, A.M.; Beier, J.C. Modeling the distribution of the West Nile and Rift Valley Fever vector Culex pipiens in arid and semi-arid regions of the Middle East and North Africa. Parasit. Vectors 2014, 7, 289. [CrossRef]

6. Petersen, L.R.; Roehrig, J.T.; Sejvar, J.J. West Nile virus in the Americas. In New and Evolving Infections of the 21st Century; Springer: Berlin/Heidelberg, Germany, 2007; pp. 3-56.

7. Rizzoli, A.; Jimenez-Clavero, M.; Barzon, L.; Cordioli, P.; Figuerola, J.; Koraka, P.; Martina, B.; Moreno, A.; Nowotny, N.; Pardigon, N. The challenge of West Nile virus in Europe: Knowledge gaps and research priorities. Euro. Surveill. 2015, 20, 21135. [CrossRef]

8. Heydari, M.; Metanat, M.; Rouzbeh-Far, M.-A.; Tabatabaei, S.M.; Rakhshani, M.; Sepehri-Rad, N.; Keshtkar-Jahromi, M. Dengue Fever as an Emerging Infection in Southeast Iran. Am. J. Trop. Med. Hyg. 2018, 98, 1469-1471. [CrossRef]

9. Ziyaeyan, M.; Behzadi, M.A.; Leyva-Grado, V.H.; Azizi, K.; Pouladfar, G.; Dorzaban, H.; Ziyaeyan, A.; Salek, S.; Hashemi, A.J.; Jamalidoust, M. Widespread circulation of West Nile virus, but not Zika virus in southern Iran. PLoS Negl. Trop. Dis. 2018, 12, e0007022. [CrossRef]

10. Naficy, K.; Saidi, S. Serological survey on viral antibodies in Iran. Trop. Geogr. Med. 1970, 22, $183-188$.

11. Saidi, S.; Tesh, R.; Javadian, E.; Nadim, A. The prevalence of human infection with West Nile virus in Iran. Iran. J. Public Health 1976, 5, 8-13.

12. Zou, S.; Foster, G.A.; Dodd, R.Y.; Petersen, L.R.; Stramer, S.L. West Nile fever characteristics among viremic persons identified through blood donor screening. J. Infect. Dis. 2010, 202, 1354-1361. [CrossRef] [PubMed]

13. Chancey, C.; Grinev, A.; Volkova, E.; Rios, M. The global ecology and epidemiology of West Nile virus. Biomed. Res. Int. 2015, 2015, 376230. [CrossRef] [PubMed]

14. Linke, S.; Ellerbrok, H.; Niedrig, M.; Nitsche, A.; Pauli, G. Detection of West Nile virus lineages 1 and 2 by real-time PCR. J. Virol. Methods 2007, 146, 355-358. [CrossRef] [PubMed]

15. Bagheri, M.; Terenius, O.; Oshaghi, M.A.; Motazakker, M.; Asgari, S.; Dabiri, F.; Vatandoost, H.; Mohammadi Bavani, M.; Chavshin, A.R. West Nile virus in mosquitoes of Iranian wetlands. Vector Borne Zoonotic Dis. 2015, 15, 750-754. [CrossRef]

16. Pesko, K.N.; Ebel, G.D. West Nile virus population genetics and evolution. Infect. Genet. Evol. 2012, 12, 181-190. [CrossRef]

17. Shah-Hosseini, N.; Chinikar, S.; Ataei, B.; Fooks, A.R.; Groschup, M.H. Phylogenetic analysis of West Nile virus genome, Iran. Emerg. Infect. Dis. 2014, 20, 1419-1421. [CrossRef]

18. Shahhosseini, N.; Chinikar, S.; Moosa-Kazemi, S.H.; Sedaghat, M.M.; Kayedi, M.H.; Lühken, R.; Schmidt-Chanasit, J. West Nile Virus lineage-2 in culex specimens from Iran. Trop. Med. Int. Health 2017, 22, 1343-1349. [CrossRef]

19. Venter, M.; Human, S.; Zaayman, D.; Gerdes, G.H.; Williams, J.; Steyl, J.; Leman, P.A.; Paweska, J.T.; Setzkorn, H.; Rous, G. Lineage 2 West Nile virus as cause of fatal neurologic disease in horses, South Africa. Emerg. Infect. Dis. 2009, 15, 877-884. [CrossRef]

20. Danis, K.; Papa, A.; Theocharopoulos, G.; Dougas, G.; Athanasiou, M.; Detsis, M.; Baka, A.; Lytras, T.; Mellou, K.; Bonovas, S. Outbreak of West Nile virus infection in Greece, 2010. Emerg. Infect. Dis. 2011, 17, 1868-1872. [CrossRef]

21. Papa, A.; Papadopoulou, E.; Chatzixanthouliou, C.; Glouftsios, P.; Pappa, S.; Pervanidou, D.; Georgiou, L. Emergence of West Nile virus lineage 2 belonging to the Eastern European subclade, Greece. Arch. Virol. 2019, 164, 1673-1675. [CrossRef] 
22. Veo, C.; Della Ventura, C.; Moreno, A.; Rovida, F.; Percivalle, E.; Canziani, S.; Torri, D.; Calzolari, M.; Baldanti, F.; Galli, M. Evolutionary dynamics of the lineage 2 West Nile virus that caused the largest European epidemic: Italy 2011-2018. Viruses 2019, 11, 814. [CrossRef] [PubMed]

23. Bakonyi, T.; Hubálek, Z.; Rudolf, I.; Nowotny, N. Novel flavivirus or new lineage of West Nile virus, central Europe. Emerg. Infect. Dis. 2005, 11, 225-231. [CrossRef] [PubMed]

24. Campbell, G.L.; Marfin, A.A.; Lanciotti, R.S.; Gubler, D.J. West Nile virus. Lancet Infect. Dis. 2002, 2, 519-529. [CrossRef]

25. Eybpoosh, S.; Fazlalipour, M.; Baniasadi, V.; Pouriayevali, M.H.; Sadeghi, F.; Vasmehjani, A.A.; Niya, M.H.K.; Hewson, R.; Salehi-Vaziri, M. Epidemiology of West Nile Virus in the Eastern Mediterranean region: A systematic review. PLoS Negl. Trop. Dis. 2019, 13, e0007081. [CrossRef]

26. Ahmadnejad, F.; Otarod, V.; Fallah, M.; Lowenski, S.; Sedighi-Moghaddam, R.; Zavareh, A.; Durand, B.; Lecollinet, S.; Sabatier, P. Spread of West Nile virus in Iran: A cross-sectional serosurvey in equines, 2008-2009. Epidemiol. Infect. 2011, 139, 1587-1593. [CrossRef]

27. Chinikar, S.; Javadi, A.; Ataei, B.; Shakeri, H.; Moradi, M.; Mostafavi, E.; Ghiasi, S.M. Detection of West Nile virus genome and specific antibodies in Iranian encephalitis patients. Epidemiol. Infect. 2012, 140, 1525-1529. [CrossRef] [PubMed]

28. Chinikar, S.; Shah-Hosseini, N.; Mostafavi, E.; Moradi, M.; Khakifirouz, S.; Jalali, T.; Goya, M.M.; Shirzadi, M.R.; Zainali, M.; Fooks, A.R. Seroprevalence of West Nile virus in Iran. Vector Borne Zoonotic Dis. 2013, 13, 586-589. [CrossRef]

29. Fereidouni, S.R.; Ziegler, U.; Linke, S.; Niedrig, M.; Modirrousta, H.; Hoffmann, B.; Groschup, M.H. West Nile virus monitoring in migrating and resident water birds in Iran: Are common coots the main reservoirs of the virus in wetlands? Vector Borne Zoonotic Dis. 2011, 11, 1377-1381. [CrossRef]

30. Sharifi, Z.; Mahmoudian, S.M.; Talebian, A. A study of West Nile virus infection in Iranian blood donors. Arch. Iran. Med. 2010, 13,1-4.

31. Zohaib, A.; Niazi, S.K.; Saqib, M.; Sajid, M.S.; Khan, I.; Athar, M.A.; Taj, Z.; Abbas, G.; Rathore, M.A.; Ghani, E. Detection of West Nile virus lineage 1 sequences in blood donors, Punjab Province, Pakistan. Int. J. Infect. Dis. 2019, 81, 137-139. [CrossRef]

32. Akıner, M.M.; Öztürk, M.; Başer, A.B.; Günay, F.; Hacıŏglu, S.; Brinkmann, A.; Emanet, N.; Alten, B.; Özkul, A.; Nitsche, A. Arboviral screening of invasive Aedes species in northeastern Turkey: West Nile virus circulation and detection of insect-only viruses. PLoS Negl. Trop. Dis. 2019, 13, e0007334. [CrossRef] [PubMed]

33. Ergunay, K.; Gunay, F.; Kasap, O.E.; Oter, K.; Gargari, S.; Karaoglu, T.; Tezcan, S.; Cabalar, M.; Yildirim, Y.; Emekdas, G. Serological, molecular and entomological surveillance demonstrates widespread circulation of West Nile virus in Turkey. PLoS Negl. Trop. Dis. 2014, 8, e3028. [CrossRef] [PubMed]

34. Ozkul, A.; Ergunay, K.; Koysuren, A.; Alkan, F.; Arsava, E.M.; Tezcan, S.; Emekdas, G.; Hacioglu, S.; Turan, M.; Us, D. Concurrent occurrence of human and equine West Nile virus infections in Central Anatolia, Turkey: The first evidence for circulation of lineage 1 viruses. Int. J. Infect. Dis. 2013, 17, e546-e551. [CrossRef] [PubMed]

35. Ocal, M.; Orsten, S.; Inkaya, A.; Yetim, E.; Acar, N.; Alp, S.; Erisoz Kasap, O.; Gunay, F.; Arsava, E.; Alten, B. Ongoing Activity of Toscana Virus Genotype A and West Nile Virus Lineage 1 Strains in T urkey: A Clinical and Field Survey. Zoonoses Public Health 2014, 61, 480-491. [CrossRef]

36. Lambrechts, L.; Chevillon, C.; Albright, R.G.; Thaisomboonsuk, B.; Richardson, J.H.; Jarman, R.G.; Scott, T.W. Genetic specificity and potential for local adaptation between dengue viruses and mosquito vectors. BMC. Evol. Biol. 2009, 9, 160. [CrossRef]

37. Brustolin, M.; Talavera, S.; Santamaría, C.; Rivas, R.; Pujol, N.; Aranda, C.; Marquès, E.; Valle, M.; Verdún, M.; Pagès, N. Culex pipiens and Stegomyia albopicta (= Aedes albopictus) populations as vectors for lineage 1 and 2 West Nile virus in Europe. Med. Vet. Entomol. 2016, 30, 166-173. [CrossRef]

38. Azari-Hamidian, S.; Norouzi, B.; Harbach, R.E. A detailed review of the mosquitoes (Diptera: Culicidae) of Iran and their medical and veterinary importance. Acta Trop. 2019, 194, 106-122. [CrossRef]

39. Azari-Hamidian, S.; Harbach, R.E. Keys to the adult females and fourth-instar larvae of the mosquitoes of Iran (Diptera: Culicidae). Zootaxa 2009, 2078, 1-33. [CrossRef]

40. Vazeille-Falcoz, M.; Mousson, L.; Rodhain, F.; Chungue, E.; Failloux, A.-B. Variation in oral susceptibility to dengue type 2 virus of populations of Aedes aegypti from the islands of Tahiti and Moorea, French Polynesia. Am. J. Trop. Med. Hyg. 1999, 60, 292-299. [CrossRef] 
41. Zakhia, R.; Mousson, L.; Vazeille, M.; Haddad, N.; Failloux, A.-B. Experimental transmission of West Nile Virus and Rift Valley Fever Virus by Culex pipiens from Lebanon. PLoS Negl. Trop. Dis. 2018, 12, e0005983. [CrossRef]

42. Murgue, B.; Murri, S.; Zientara, S.; Durand, B.; Durand, J.-P.; Zeller, H. West Nile outbreak in horses in southern France, 2000: The return after 35 years. Emerg. Infect. Dis. 2001, 7, 692-696. [CrossRef] [PubMed]

43. Igarashi, A. Isolation of a Singh's Aedes albopictus cell clone sensitive to Dengue and Chikungunya viruses. J. Gen. Virol. 1978, 40, 531-544. [CrossRef] [PubMed]

44. Dubrulle, M.; Mousson, L.; Moutailler, S.; Vazeille, M.; Failloux, A.-B. Chikungunya virus and Aedes mosquitoes: Saliva is infectious as soon as two days after oral infection. PLoS ONE 2009, 4, e5895. [CrossRef] [PubMed]

45. Jupille, H.; Seixas, G.; Mousson, L.; Sousa, C.A.; Failloux, A.-B. Zika virus, a new threat for Europe? PLoS Negl. Trop. Dis. 2016, 10, e0004901. [CrossRef] [PubMed]

46. Chouin-Carneiro, T.; Vega-Rua, A.; Vazeille, M.; Yebakima, A.; Girod, R.; Goindin, D.; Dupont-Rouzeyrol, M.; Lourenco-de-Oliveira, R.; Failloux, A.-B. Differential susceptibilities of Aedes aegypti and Aedes albopictus from the Americas to Zika virus. PLoS Negl. Trop. Dis. 2016, 10, e0004543. [CrossRef]

47. Amraoui, F.; Krida, G.; Bouattour, A.; Rhim, A.; Daaboub, J.; Harrat, Z.; Boubidi, S.-C.; Tijane, M.; Sarih, M.; Failloux, A.-B. Culex pipiens, an experimental efficient vector of West Nile and Rift Valley fever viruses in the Maghreb region. PLoS ONE 2012, 7, e36757. [CrossRef]

48. Balenghien, T.; Vazeille, M.; Grandadam, M.; Schaffner, F.; Zeller, H.; Reiter, P.; Sabatier, P.; Fouque, F.; Bicout, D.J. Vector competence of some French Culex and Aedes mosquitoes for West Nile virus. Vector Borne Zoonotic Dis. 2008, 8, 589-596. [CrossRef]

49. Balenghien, T.; Vazeille, M.; Reiter, P.; Schaffner, F.; Zeller, H.; Bicout, D.J. Evidence of laboratory vector competence of Culex modestus for West Nile virus. J. Am. Mosq. Control. Assoc. 2007, 23, 233-237. [CrossRef]

50. Ebel, G.D.; Rochlin, I.; Longacker, J.; Kramer, L.D. Culex restuans (Diptera: Culicidae) relative abundance and vector competence for West Nile Virus. J. Med. Entomol. 2005, 42, 838-843. [CrossRef]

51. Goddard, L.B.; Roth, A.E.; Reisen, W.K.; Scott, T.W. Vector competence of California mosquitoes for West Nile virus. Emerg. Infect. Dis. 2002, 8, 1385-1391. [CrossRef]

52. Sardelis, M.R.; Turell, M.J.; Dohm, D.J.; O'Guinn, M.L. Vector competence of selected North American Culex and Coquillettidia mosquitoes for West Nile virus. Emerg. Infect. Dis. 2001, 7, 1018-1022. [CrossRef] [PubMed]

53. Turell, M.J.; Dohm, D.J.; Sardelis, M.R.; O'guinn, M.L.; Andreadis, T.G.; Blow, J.A. An update on the potential of North American mosquitoes (Diptera: Culicidae) to transmit West Nile virus. J. Med. Entomol. 2005, 42, 57-62. [CrossRef] [PubMed]

54. Turell, M.J.; O'Guinn, M.L.; Dohm, D.J.; Webb, J.P., Jr.; Sardelis, M.R. Vector competence of Culex tarsalis from orange County, California, for West Nile virus. Vector Borne Zoonotic Dis. 2002, 2, 193-196. [CrossRef] [PubMed]

55. Vogels, C.; Göertz, G.; Pijlman, G.; Koenraadt, C. Vector competence of northern and southern European Culex pipiens pipiens mosquitoes for West Nile virus across a gradient of temperatures. Med. Vet. Entomol. 2017, 31, 358-364. [CrossRef]

56. Flores, F.S.; Zanluca, C.; Guglielmone, A.A.; Duarte Dos Santos, C.N.; Labruna, M.B.; Diaz, A. Vector Competence for West Nile Virus and St. Louis Encephalitis Virus (Flavivirus) of Three Tick Species of the Genus Amblyomma (Acari: Ixodidae). Am. J. Trop. Med. Hyg. 2019, 100, 1230-1235. [CrossRef]

57. Zaim, M. The distribution and larval habitat characteristics of Iranian Culicinae. J. Am. Mosq. Control. Assoc. 1987, 3, 568-573.

58. Ciota, A.T.; Kramer, L.D. Vector-virus interactions and transmission dynamics of West Nile virus. Viruses 2013, 5, 3021-3047. [CrossRef]

59. Hutcheson, H.J.; Gorham, C.H.; Machain-Williams, C.; Loroño-Pino, M.A.; James, A.M.; Marlenee, N.L.; Winn, B.; Beaty, B.J.; Blair, C.D. Experimental transmission of West Nile virus (Flaviviridae: Flavivirus) by Carios capensis ticks from North America. Vector Borne Zoonotic Dis. 2005, 5, 293-295. [CrossRef]

60. Moro, C.V.; Chauve, C.; Zenner, L. Vectorial role of some dermanyssoid mites (Acari, Mesostigmata, Dermanyssoidea). Parasite 2005, 12, 99-109. [CrossRef]

61. Tempelis, C.H. Host-feeding patterns of mosquitoes, with a review of advances in analysis of blood meals by serology. J. Med. Entomol. 1975, 11, 635-653. [CrossRef] 
62. Kramer, L.D.; Ebel, G.D. Dynamics of flavivirus infection in mosquitoes. Adv. Viruses Res. 2003, 60, $187-232$.

63. Anderson, S.L.; Richards, S.L.; Tabachnick, W.J.; Smartt, C.T. Effects of West Nile virus dose and extrinsic incubation temperature on temporal progression of vector competence in Culex pipiens quinquefasciatus. J. Am. Mosq. Control. Assoc. 2010, 26, 103-107. [CrossRef] [PubMed]

64. Paz, S. Effects of climate change on vector-borne diseases: An updated focus on West Nile virus in humans. Emerg. Top. Life Sci. 2019, 3, 143-152.

65. Turell, M.; O'Guinn, M.; Oliver, J. Potential for New York mosquitoes to transmit West Nile virus. Am. J. Trop. Med. Hyg. 2000, 62, 413-414. [CrossRef] [PubMed]

66. Fansiri, T.; Fontaine, A.; Diancourt, L.; Caro, V.; Thaisomboonsuk, B.; Richardson, J.H.; Jarman, R.G.; Ponlawat, A.; Lambrechts, L. Genetic mapping of specific interactions between Aedes aegypti mosquitoes and dengue viruses. PLoS Genet. 2013, 9, e1003621. [CrossRef]

(C) 2020 by the authors. Licensee MDPI, Basel, Switzerland. This article is an open access article distributed under the terms and conditions of the Creative Commons Attribution (CC BY) license (http://creativecommons.org/licenses/by/4.0/). 